\title{
Pembentukan Pupuk Struvite dari Limbah Cair Industri Tempe dengan Proses Aerasi
}

\section{The Formation of Struvite Fertilizer from Tempeh Industrial Wastewater by Aeration Process}

\author{
LULUK EDAHWATI*, SUTIYONO, DAN RIZQI RENDRI ANGGRIAWAN \\ Program Studi Teknik Kimia, Fakultas Teknik, UPN “Veteran” Jawa Timur \\ Jalan Rungkut Madya No. 1, Gunung Anyar, Surabaya 60294 \\ Email : lulukedahwati@gmail.com
}

\begin{abstract}
Struvite, also known as magnesium ammonium phosphate hexahydrate, is a white crystal with a chemical formula magnesium ammonium phosphate hexahydrate $\left(\mathrm{MgNH}_{4} \mathrm{PO}_{4} \cdot 6 \mathrm{H}_{2} \mathrm{O}\right)$. Because of its phosphate content, struvite can be utilized as a fertilizer. Tempeh industrial effluent contains a high concentration of $\mathrm{PO}_{4}$, making it a possible struvite fertilizer producing material. The formation of struvite fertilizer is carried out by the aeration process. This process is able to increase the $\mathrm{pH}$ and homogeneity of the solution. The solution of Magnesium Ammonium Phosphate (MAP) is prepared by reacting tempeh industrial wasterwater, Magnesium Chloride $\left(\mathrm{MgCl}_{2}\right)$, and Ammonium Hydroxide $\left(\mathrm{NH}_{4} \mathrm{OH}\right)$. The MAP ratios used are 1:1:1 and 3:1:1. The temperature was set at $30^{\circ} \mathrm{C}$ and $\mathrm{pH}$ 9, the airflow rate was carried out at a rate of 0.25 - 1.25 liters per minute. Struvite crystals were analyzed using X-ray Fluorescence (XRF) and Scanning Electron Microscope (SEM). The best struvite fertilizer content is magnesium by $40.3 \%$ and phosphorus by $43.9 \%$ at an air flow rate of 1.25 liters per minute and a ratio of 3:1:1. Further development can be done by applying struvite fertilizers to plants.
\end{abstract}

Keywords: aeration, crystallization, tempeh industrial wastewater, struvite

\section{ABSTRAK}

Struvite adalah kristal putih yang secara kimiawi dikenal sebagai magnesium amonium fosfat heksahidrat $\left(\mathrm{MgNH}_{4} \mathrm{PO}_{4} \cdot 6 \mathrm{H}_{2} \mathrm{O}\right)$. Struvite dapat dimanfaatkan menjadi pupuk karena kandungan fosfat $\left(\mathrm{PO}_{4}\right)$ di dalamnya. Limbah cair industri tempe memiliki kandungan $\mathrm{PO}_{4}$ yang cukup tinggi, menjadikan limbah cair industri tempe adalah bahan pembentuk pupuk struvite yang potensial. Pembentukan pupuk struvite dilakukan dengan proses aerasi. Proses ini mampu meningkatkan $\mathrm{pH}$ dan homogenitas dari larutan. Larutan MAP (Magnesium Amonium Fosfat) dibuat dengan cara mereaksikan limbah cair industri tempe, Magnesium Klorida $\left(\mathrm{MgCl}_{2}\right)$, dan Amonium Hidroksida $\left(\mathrm{NH}_{4} \mathrm{OH}\right)$. Rasio MAP yang digunakan adalah 1:1:1 dan $3: 1: 1$. Temperatur ditetapkan sebesar $30^{\circ} \mathrm{C}$ dan $\mathrm{pH}$ 9, laju alir udara dilakukan dengan laju 0,25 - 1,25 liter per menit. Kristal struvite dianalisis menggunakan Floresensi sinar-X (XRF) dan Mikroskop Pemindai Elektron (SEM). Kandungan pupuk struvite terbaik adalah magnesium sebesar $40,3 \%$ dan fosfor sebesar 43,9\% pada konsentrasi 3:1:1 dan laju alir udara 1,25 liter per menit. Pengembangan lebih lanjut dapat dilakukan dengan mengaplikasikan pupuk struvite ke tanaman.

Kata Kunci: aerasi, kristalisasi, limbah cair industri tempe, struvite

\section{PENDAHULUAN}

\subsection{Latar Belakang}

Struvite (Magnesium Ammonium Phosphate) adalah sejenis kristal putih yang mengandung unsur magnesium, amonium, dan fosfat. Rumus molekul dari struvite adalah $\mathrm{MgNH}_{4} \mathrm{PO}_{4} \cdot 6 \mathrm{H}_{2} \mathrm{O}$. Proses pembentukan struvite adalah dengan cara mereaksikan senyawa $\mathrm{Mg}^{2+}$ (magnesium), $\mathrm{NH}_{4}{ }^{+}$(amonium), dan $\mathrm{PO}_{4}{ }^{3-}$ (fosfat). Reaksi pembentukan kristal struvite terjadi apabila konsentrasi reaktan pembentuk struvite dalam larutan melebihi kelarutan produk yang dihasilkan (Ksp). Sehingga terbentuk struvite sesuai reaksi mengikuti persamaan dibawah ini $^{(1-3)}$.

$\mathrm{Mg}^{2+}+\mathrm{NH}_{4}{ }^{+}+\mathrm{PO}_{4}{ }^{3-}+6 \mathrm{H}_{2} \mathrm{O} \rightarrow \mathrm{MgNH}_{4} \mathrm{PO}_{4} 6 \mathrm{H}_{2} \mathrm{O} \ldots$

Unsur yang terkandung dalam kristal struvite merupakan unsur-unsur yang juga diperlukan oleh tanaman, sehingga kristal struvite dapat digunakan sebagai bahan baku dalam pembuatan pupuk untuk tanaman. Pupuk struvite dapat juga disebut sebagai pupuk yang tidak mudah larut atau pelepasan nutrisinya 
secara perlahan (slow release fertilizer) ${ }^{(4,5)}$. Kristal struvite mengandung unsur fosfor yang dapat digunakan sebagai alternatif bahan pembuatan pupuk struvite ${ }^{(6,7)}$. Produksi pupuk yang mengandung fosfor selama ini menggunakan batuan fosfat sebagai sumber fosfornya. Jika batuan fosfat ini diambil secara terus menerus maka sumber batuan fosfat ini lama kelamaan akan habis ${ }^{(8,9)}$. Pupuk struvite ini memiliki beberapa kelebihan dibandingkan dengan pupuk yang lain diantaranya adalah mempunyai daya larut yang rendah terhadap air, mudah dibuat, memiliki kandungan yang lebih murni, mudah dalam pemakaian, tidak berbau, dan nutrisi terkonsentrasi pada satu kesatuan $^{(10,11)}$. Oleh karena itu, struvite yang dipergunakan sebagai pupuk hanya perlu ditambahkan sesekali pada tanaman karena sifatnya yang slow release ${ }^{(12)}$.

Pada cairan limbah dari suatu industri, mengandung beberapa kandungan seperti nitrogen $(N)$, fosfor $(P)^{(13)}$, macam-macam logam berat ${ }^{(14)}$, dan masih banyak lagi. Seperti penelitian yang telah dilakukan tentang produksi pupuk berpelepas lambat (slow release fertilizer) dari limbah cair dengan metode kristalisasi struvite ${ }^{(5)}$.

Pengambilan senyawa $\mathrm{PO}_{4}$ dari limbah rumah sakit dalam bentuk kristal struvite untuk kemudian dijadikan pupuk struvite. Dalam penelitiannya, kristal struvite yang paling banyak terbentuk pada $\mathrm{pH} 9$ dan recovery $\mathrm{PO}_{4}$ sebanyak $83,7 \%{ }^{(3)}$.

Pembentukan kristal struvite dari sebuah limbah sintetis dapat dilakukan dengan menggunakan reaktor fluidized bed. Dari studi yang telah dilakukan, kondisi yang optimal dalam studinya yaitu pada $\mathrm{pH}$ 9,5 dengan rasio molar Mg:N:P = 1,3:4:1 dan didapat perolehan fosfat serta rasio kristalisasi adalah $95,8 \%$ dan $93,5 \%{ }^{(15)}$.

Pengaruh $\mathrm{pH}$ larutan merupakan salah satu faktor yang paling penting untuk proses reaksi pembentukan kristal struvite. Peningkatan $\mathrm{pH}$ larutan dari 8 - 9 mengakibatkan efisiensi recovery fosfat sampai $80 \%$ dan terjadi penurunan ketika $\mathrm{pH}$ larutan diatas $10^{(16)}$. Hal ini dikarenakan pada $\mathrm{pH}$ diatas 10 akan cenderung membentuk $\mathrm{Mg}(\mathrm{OH})_{2}$ sehingga menurunkan ketersediaan ion $\mathrm{Mg}^{2+}$ yang dapat menurunkan produktivitas pembentukan kristal struvite ${ }^{(3)}$.

Pengadukan menjadi salah satu aspek yang penting dalam proses kristalisasi, karena peningkatan kecepatan pengadukan akan mempengaruhi kecepatan reaksi pembentukan kristal yang terjadi dalam sistem, meningkatkan ukuran partikel, dan kecepatan pengendapan. Proses pembentukan struvite dengan reaktor berpengaduk jarang digunakan karena kristal struvite yang terbentuk dapat pecah akibat tumbukan antar kristal, pengaduk, dan tangki. Selain itu, proses pembentukan kristal dengan bantuan bibit kristal mengakibatkan kemurnian produk menurun $^{(3,17)}$.

Pada penelitian ini, proses pembentukan struvite terjadi pada tangki aerasi. Aerasi (memasukkan udara dengan kecepatan tertentu) selain untuk membantu meningkatkan $\mathrm{pH}$ pada larutan dapat juga digunakan sebagai proses pengadukan pada larutan ${ }^{(18)}$. Semakin besar laju aerasi yang digunakan maka semakin cepat terbentuk struvite. Udara akan menyebabkan larutan yang ada di dalam reaktor bergejolak sehingga luas permukaan sentuhannya akan menjadi semakin besar. Kemudian meningkatkan kecepatan terjadinya reaksi. Dengan memberikan gelembung udara dan membiarkannya naik sehingga tercapai homogenitas pada larutan ${ }^{(19)}$. Laju alir udara juga memainkan peran yang penting dalam meremoval $\mathrm{NH}_{4}-\mathrm{N}$ dari suatu larutan ${ }^{(20)}$, bahkan laju alir udara dapat mengencerkan konsentrasi fase gas $\mathrm{NH}_{4}-\mathrm{N}$ dan mendorong peningkatan pelarutan $\mathrm{NH}_{4}-\mathrm{N}$ untuk berpisah pada fase gas $^{(21)}$. Jadi, ada kecenderungan dalam peningkatan volatilisasi amonia dengan meningkatnya laju alir udara.

Waktu aerasi yang cukup akan memperoleh efisiensi removal $\mathrm{NH}_{4}-\mathrm{N}$ yang tinggi. Mereka menemukan bahwa 93,4\% $\quad \mathrm{NH}_{4}-\mathrm{N}$ removal dengan laju aerasi 0,6 liter per menit dengan periode waktu 24 jam dan $95,3 \% \mathrm{NH}_{4}-\mathrm{N}$ removal dengan laju aerasi 10 liter per menit dengan waktu 12 jam. Akan tetapi kandungan nitrogen dalam mineral struvite harus berkurang/kecil karena unsur nitrogen akan menghambat proses evaporasi pada tanaman khusunya tanaman pohon buah seperti pohon buah apel, pohon buah mangga, dan sebagainya ${ }^{(22)}$.

Teknik yang efektif untuk optimalisasi proses berlangsungnya pembentukan kristal struvite adalah dengan memilih parameter optimal, misalnya pengaruh suhu atau temperatur, rasio molar, dan $\mathrm{pH}$. Struvite yang terbentuk dapat dianalisis dengan XRF (X-ray Fluorescence) untuk mengetahui komposisi fase mineral. Serta SEM (Scanning Electron Microscope) untuk melihat bentuk morfologi kristal struvite ${ }^{(23)}$.

Limbah cair industri tempe dihasilkan dari proses pencucian kedelai, proses perendaman, perebusan, dan pemasakan dalam pembuatan tempe. Limbah cair industri tempe memiliki kandungan fosfat $\left(\mathrm{PO}_{4}\right)$ yang cukup tinggi. Kandungan $\mathrm{PO}_{4}$ pada limbah cair industri tempe berkisar $\pm 1089,3 \mathrm{mg} / \mathrm{L}$. Kandungan fosfat pada limbah cair tempe sangat diperlukan untuk tumbuhan sebagai nutrisi untuk pertumbuhan tanaman. Kandungan fosfat pada limbah cair industri tempe ini dapat dimanfaatkan menjadi 
salah satu bahan pembentuk pupuk struvite. Caranya yakni mereaksikannya dengan senyawa Magnesium (Mg) dan Amonium $\left(\mathrm{NH}_{4}\right)^{(24)}$.

\subsection{Tujuan Penelitian}

Tujuan dari penelitian ini adalah untuk memproduksi pupuk struvite dengan proses aerasi dari limbah cair industri tempe. Selain itu, untuk memperoleh kandungan $\mathrm{Mg}$ dan $\mathrm{PO}_{4}$ pada pupuk struvite dengan mutu yang baik.

\section{BAHAN DAN METODE}

\subsection{Bahan}

Bahan yang digunakan dalam penelitian adalah limbah cair industri tempe sebagai sumber $\mathrm{PO}_{4}$. Sedangkan bahan lainnya dibeli di Bratachem, Surabaya yaitu Magnesium Klorida $\left(\mathrm{MgCl}_{2}\right)$ sebagai sumber $\mathrm{Mg}$, Amonium Hidroksida $\left(\mathrm{NH}_{4} \mathrm{OH}\right)$ sebagai sumber $\mathrm{NH}_{4}$, dan
Kalium Hidroksida $(\mathrm{KOH})$ sebagai pengatur $\mathrm{pH}$ menjadi basa.

\subsection{Metode}

Membuat larutan MAP dengan perbandingan konsentrasi $\mathrm{Mg}: \mathrm{NH}_{4}: \mathrm{PO}_{4}=1: 1: 1$ dan 3:1:1 serta larutan $\mathrm{KOH} 1 \mathrm{~N}$. Larutan MAP (1:1:1) dimasukkan ke dalam tangki pertama kemudian di pompa ke dalam tangki aerasi. Laju alir udara dimasukkan ke dalam tangki aerasi dengan kecepatan 0,$25 ; 0,5 ; 0,75 ; 1$; dan 1,25 liter per menit. Larutan $\mathrm{KOH}$ dimasukkan setetes demi setetes sampai $\mathrm{pH}$ 9. Setelah $\mathrm{pH}$ tercapai proses aerasi tetap dilakukan sampai $\mathrm{pH}$ yang didapat benar-benar konstan. Setelah itu endapan yang terjadi disaring kemudian dikeringkan dengan cara diangin-anginkan selama kurang lebih 48 jam. Prosedur yang sama dilakukan untuk konsentrasi MAP (3:1:1). Endapan yang didapat, dianalisis XRF untuk mengetahui persentase $\mathrm{Mg}$ dan $\mathrm{P}$ pada struvite. Analisa SEM untuk mengetahui bentuk karakteristik dari struvite yang dihasilkan.

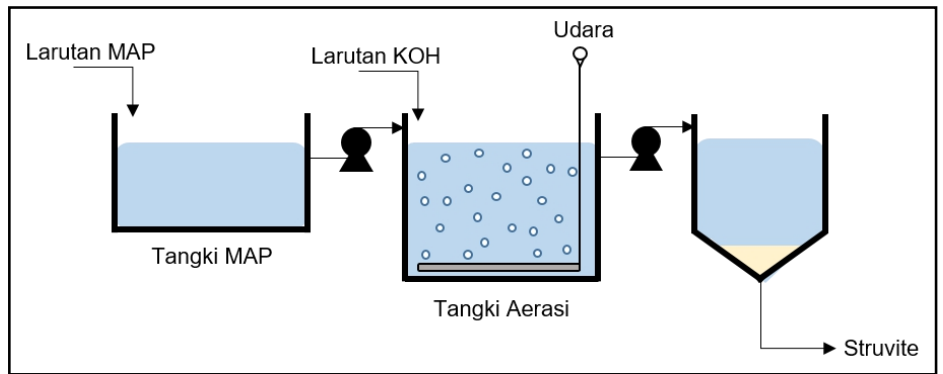

Gambar 1. Rangkaian Alat Pembentukan Struvite

\section{HASIL DAN PEMBAHASAN}

\subsection{Kandungan Magnesium dan Fosfor pada Pupuk Struvite}

Penelitian yang dilakukan menggunakan variabel laju alir udara 0,$25 ; 0,5 ; 0,75 ; 1$; dan 1,25 liter per menit pada rasio molar MAP 1:1:1 dan 3:1:1. Pengaruh laju alir udara pada perolehan magnesium dan fosfor struvite ditunjukkan pada Gambar 2 dan Gambar 3.

Pada rasio molar 1:1:1 yang ditunjukkan pada Gambar 2, perolehan magnesium (\% Mg) mencapai kondisi tertinggi pada laju alir udara 0,75 liter per menit sebesar $26,53 \%$. Kemudian mengalami penurunan pada laju alir udara 1 liter per menit menjadi sebesar $23,56 \%$. Hal yang sama terjadi pada perolehan fosfor ( $\% \mathrm{P})$, dimana pada laju alir 1 liter per menit adalah perolehan fosfor tertinggi pada rasio molar 1:1:1 sebesar $37,63 \%$. Kemudian mengalami penurunan pada laju 1,25 liter per menit menjadi sebesar $28,17 \%$. Penurunan ini terjadi akibat pertumbuhan kristal pada laju alir yang besar mengalami perlambatan. Semakin cepat kontak antar komponen penyusun struvite mengakibatkan pertumbuhan kristalnya tidak sempurna. Pengadukan dengan laju yang besar mengakibatkan waktu induksi berkurang dan nukleasi akan terjadi lebih cepat. Pada laju alir yang lebih besar, larutan MAP dipaksa lebih cepat mengkristal menjadi struvite. Kemudian kristal struvite akan terdorong ke atas pada tangki aerasi dan menyebabkan kristal masuk secara overflow ke bagian tangki pengendapan. Magnesium yang terkandung mengalami penurunan stabilitas pada kristal struvite dan menyebabkan kristal pecah ${ }^{(21,25)}$. Apabila inti kristal tidak stabil, maka kristal cenderung larut kembali pada larutan ${ }^{(19)}$. Pada laju alir yang tinggi, struvite tidak mampu bertahan sehingga kristal akan kembali larut pada larutan. Sedangkan pada pembentukan struvite kembali dibutuhkan waktu kontak yang lebih lama pada proses pertumbuhan kristal(26). Berbeda dengan laju alir udara yang lebih kecil, larutan MAP akan terkonversi menjadi kristal struvite pada waktu yang lebih lama di tangki aerasi, memberikan kesempatan pada ion-ion magnesium, amonium, dan fosfat berikatan pada kristal struvite. 


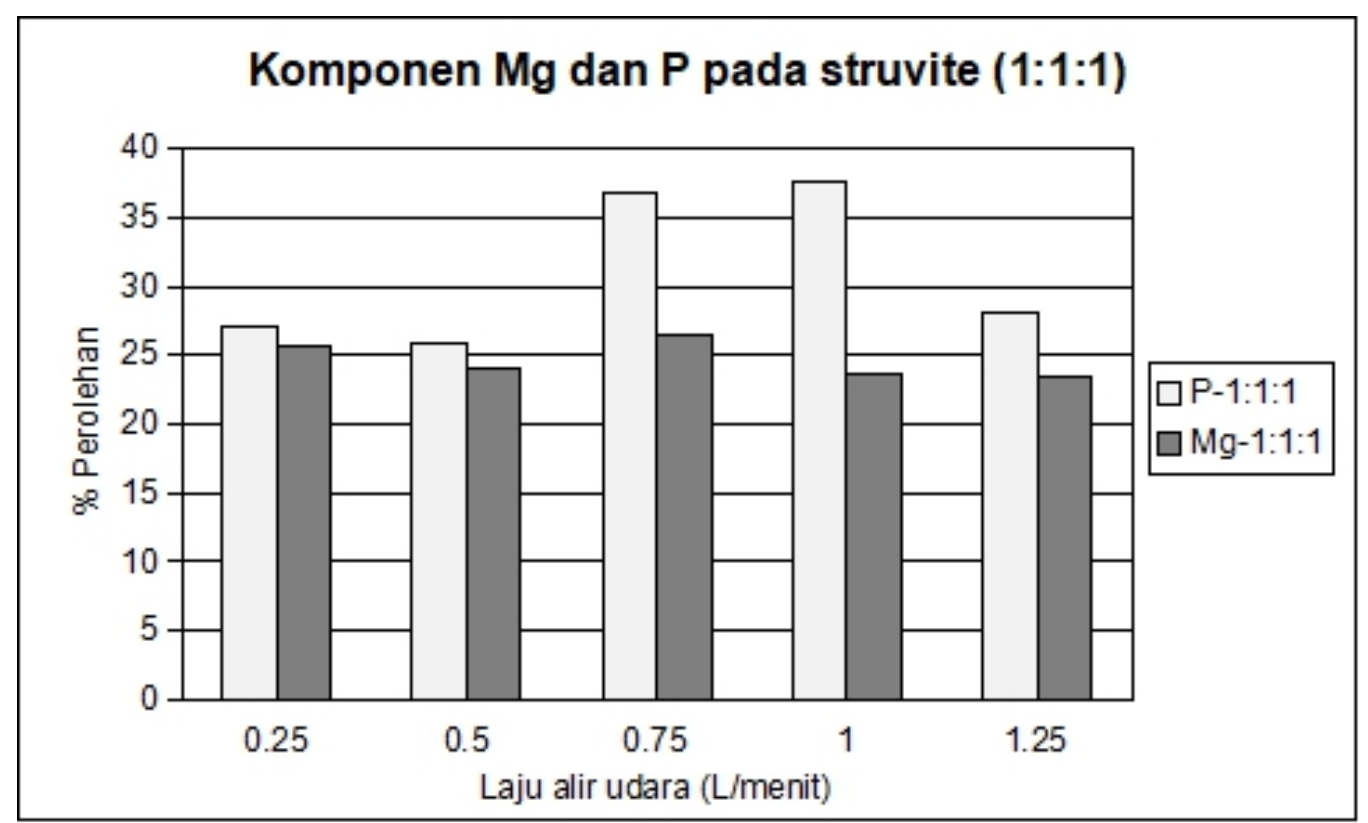

Gambar 2. Perolehan magnesium dan fosfor pada rasio molar 1:1:1

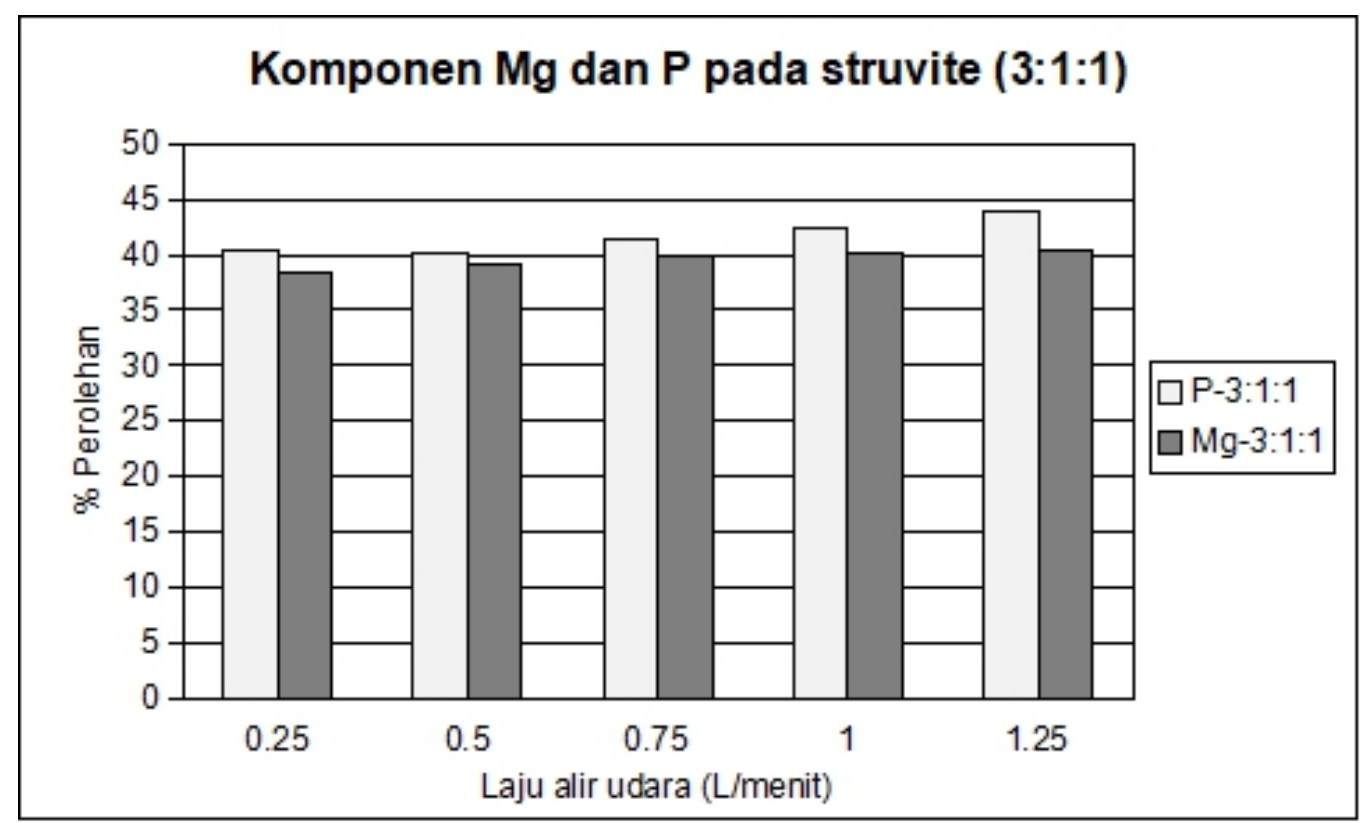

Gambar 3. Perolehan magnesium dan fosfor pada rasio molar 3:1:1

Berbeda dengan rasio 3:1:1 pada Gambar 3 menunjukkan bahwa perolehan magnesium dan fosfor meningkat seiring dengan meningkatnya laju alir udara. Hal ini dikarenakan laju alir udara berfungsi sebagai pengganti pengaduk ${ }^{(17)}$. Udara yang masuk ke dalam tangki aerasi menggerakkan komponen magnesium, amonium, dan fosfat untuk saling berikatan dalam kondisi basa berkat penambahan $\mathrm{KOH}$ membentuk kristal struvite. Semakin tinggi laju alir udara sama halnya mempercepat proses reaksi antara komponen magnesium, amonium, dan fosfat untuk saling bereaksi membentuk struvite $^{(9,27)}$. Pembentukan mineral struvite ini dapat mengkonversi magnesium sebesar $40,3 \%$ dan fosfor sebesar $43,9 \%$ pada laju alir udara
1,25 liter per menit. Rasio 3:1:1 memiliki konsentrasi reaktan magnesium yang lebih tinggi daripada rasio 1:1:1. Dengan penambahan rasio molar MAP menjadi 3:1:1, mengakibatkan magnesium mempengaruhi tingkat saturasi larutan. Sehingga reaksi pembentukan struvite dapat meningkat seiring dengan bertambahnya rasio molar ${ }^{(28)}$. Hal inilah yang menyebabkan hasil perolehan baik persentase $\mathrm{Mg}$ dan persentase $\mathrm{P}$ pada rasio molar 3:1:1 lebih tinggi daripada rasio 1:1:1.

Menurut penelitian terdahulu yang telah dilakukan, pembentukan struvite idealnya dilakukan pada laju aerasi udara sebesar 0,73 liter per menit ${ }^{(29)}$. Adapun penelitian lain memberikan hasil optimum untuk laju aerasi 
pada pembentukan struvite adalah sebesar 0,75 liter per menit(21).

Tren yang berbeda dari kedua kurva baik dari rasio molar 1:1:1 dan 3:1:1 disebabkan penambahan magnesium berlebih, hal ini memberikan kesempatan komponen untuk berikatan lebih banyak lagi. Dengan penambahan magnesium, didapatkan perolehan magnesium yang lebih besar, mulai dari 38,4 $40,3 \%$ berbeda dengan perolehan magnesium pada rasio 1:1:1 yang berkisar $25,71-26,53 \%$. Pada Tabel 1 berdasarkan kandungan $P$, menurut SNI 02-3776-2005 pupuk struvite yang dihasilkan pada penelitian ini memiliki tingkat mutu yang baik. Namun demikian perlu dikaji penerapan pupuk struvite kepada tanaman untuk mengetahui efektivitas kandungan di dalamnya.

Tabel 1. Mutu pupuk struvite berdasarkan kandungan $\mathrm{P}$ sebagai $\mathrm{P}_{2} \mathrm{O}_{5}$

\begin{tabular}{cccc}
\hline $\begin{array}{c}\text { Rasio } \\
\text { MAP }\end{array}$ & $\begin{array}{c}\text { Laju Alir (liter } \\
\text { per menit) }\end{array}$ & $\mathbf{P}$ (\%) & Mutu \\
\hline 1:1:1 & 0,25 & 27 & $\mathrm{~B}$ \\
\cline { 2 - 4 } & 0,5 & 25,81 & $\mathrm{~B}$ \\
\cline { 2 - 4 } & 0,75 & 36,74 & $\mathrm{~A}$ \\
\cline { 2 - 4 } & 1 & 37,63 & $\mathrm{~A}$ \\
\hline $3: 1: 1$ & 1,25 & 28,17 & $\mathrm{~A}$ \\
\cline { 2 - 4 } & 0,25 & 40,5 & $\mathrm{~A}$ \\
\cline { 2 - 4 } & 0,5 & 40,2 & $\mathrm{~A}$ \\
\hline & 0,75 & 41,4 & $\mathrm{~A}$ \\
\hline & 1 & 42,4 & $\mathrm{~A}$ \\
\hline & 1,25 & 43,9 & $\mathrm{~A}$ \\
\hline
\end{tabular}

\subsection{Karateristik Morfologi Struvite}

Bentuk karakteristik morfologi pada struvite dapat dilakukan dengan analisa SEM (Scanning Electron Microscope). Pada Gambar 4, bentuk morfologi dari kristal struvite adalah ortorombik dengan bentuk yang memanjang. Pada rasio molar 3:1:1 terdapat beberapa kristal yang garis kristalnya tidak lancip dan bercabang. Penambahan magnesium dalam pembentukan struvite beresiko atas tersusunnya senyawa lain ${ }^{(30)}$. Sehingga kristal struvite yang digambarkan mengalami perubahan dari bentuk struvite kondisi murni. Adapun pada rasio molar 1:1:1 menghasilkan bentuk kristal dengan sudut garis yang jelas. Seperti yang ditunjukkan pada penelitian lainnya, hasil SEM untuk rasio molar 1:1:1 menghasilkan bentuk kristal yang lebih baik $^{(5)}$.

Dilihat dari segi ukuran kristal, rasio 1:1:1 memiliki rata-rata ukuran kristal $20 \mu \mathrm{m}$ lebih kecil daripada ukuran kristal rasio 3:1:1 yang sebesar $50 \mu \mathrm{m}$. Kristal dengan ukuran lebih besar biasanya didapatkan pada beberapa penelitian yang menggunakan rasio molar lebih tinggi, diakibatkan adanya penambahan senyawa magnesium berlebih ${ }^{(31)}$. Magnesium merupakan unsur hara sekunder yang dibutuhkan tanaman ${ }^{(32)}$. Sehingga tidak diperlukan kandungan magnesium dalam jumlah besar pada pupuk. Ukuran kristal struvite yang lebih kecil memiliki total luas permukaan yang lebih besar sehingga akan mempercepat kelarutan suatu zat ${ }^{(33)}$, dan proses penyerapan nutrisi pupuk dapat berlangsung lebih cepat. Mengingat struvite adalah pupuk lepas lambat, sehingga ukuran kristal yang lebih besar menyebabkan nutrisi pada pupuk terserap lebih lambat oleh tanaman. (a)

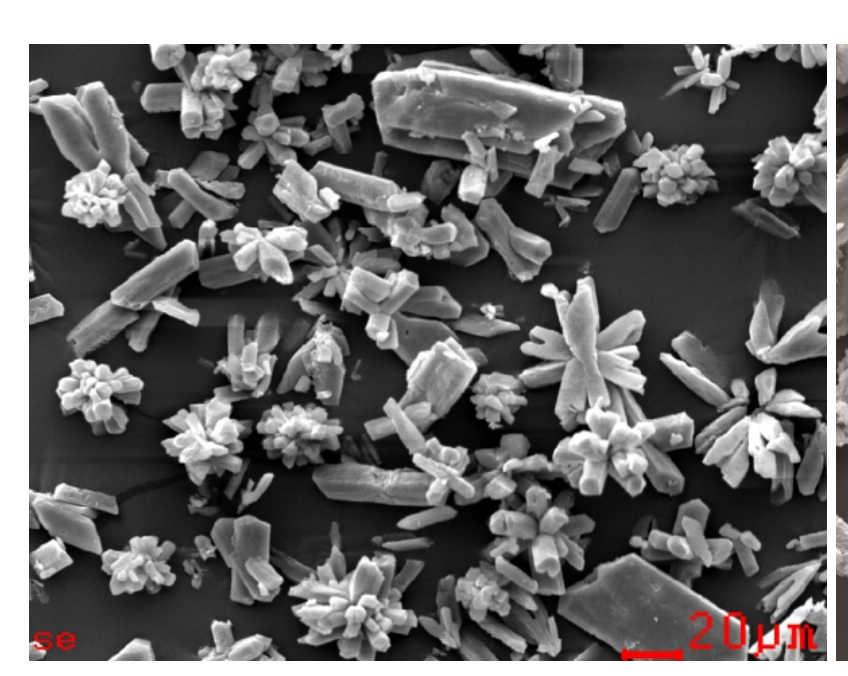

Gambar 4. (a) Hasil SEM pada rasio molar 1:1:1 (b) Hasil SEM pada rasio molar 3:1:1 


\section{KESIMPULAN}

Pembentukan struvite dari limbah cair industri tempe menghasilkan perolehan magnesium dan fosfor terbaik pada rasio molar 3:1:1 dan laju alir 1,25 liter per menit sebesar $40,3 \% \mathrm{Mg}$ dan $43,9 \%$ P. Pada rasio molar 1:1:1, didapatkan perolehan magnesium terbaik pada laju alir 0,75 liter per menit sebesar 26,53\% Mg. Adapun perolehan fosfor terbaik pada laju alir 1 liter per menit sebesar $37,63 \%$ P. Penambahan magnesium pada larutan MAP mengakibatkan peningkatan perolehan magnesium dan fosfor namun dapat membentuk senyawa lain sehingga kemurnian struvite berkurang seperti yang ditunjukkan pada hasil SEM. Semakin tinggi laju alir udara pada proses aerasi mengakibatkan kristal tidak stabil dan pecah akibat tingginya tumbukan antar kristal. Diperlukan penelitian lebih lanjut untuk mengetahui efektivitas struvite sebagai pupuk kepada tanaman.

\section{PERSANTUNAN}

Puji syukur kami panjatkan kehadirat Allah SWT atas rahmat dan karunia-Nya, sehingga tim penulis dapat menyelesaikan artikel ini. Penulis menyampaikan terima kasih kepada Universitas Pembangunan Nasional "Veteran" Jawa Timur yang telah mendukung program Riset Dasar Lanjutan ini.

\section{DAFTAR PUSTAKA}

1. Ali, M. I. (2005). Struvite Crystallization from Nutrient Rich Wastewater. , Ph.D. dissertation, School of Engineering, James Cook University, Townsville, Australia.

2. Corre, K. S. Le. (2006). Understanding Struvite Crystallisation and Recovery Supervisor. , Ph.D. dissertation, Department of Sustainable Systems, Cranfield University, Cranfield, UK.

3. Ariyanto, E., Melani, A., \& Anggraini, T. (2015). Penyisihan PO4 Dalam air Limbah Rumah Sakit Untuk Produksi Pupuk Struvite. Jurnal.Ftumj, 1-8.

4. de-Bashan, L. E., \& Bashan, Y. (2004). Recent advances in removing phosphorus from wastewater and its future use as fertilizer (1997-2003). Water Research, 38(19), 42224246.

5. Rahman, M. M., Salleh, M. A. M., Rashid, U., Ahsan, A., Hossain, M. M., \& Ra, C. S. (2014). Production of slow release crystal fertilizer from wastewaters through struvite crystallization - A review. Arabian Journal of Chemistry, 7(1), 139-155.
6. Münch, E. V, \& Barr, K. (2001). Controlled struvite crystallisation for removing phosphorus from anaerobic digester sidestreams. Water Research, 35(1), 151-159.

7. Massey, M. S., Davis, J. G., Sheffield, R. E., \& Ippolito, J. A. (2007). Struvite production from dairy wastewater and its potential as a fertilizer for organic production in calcareous soils. ASABE - Proceedings of the International Symposium on Air Quality and Waste Management for Agriculture, September.

8. Shu, L., Schneider, P., Jegatheesan, V., \& Johnson, J. (2006). An Economic Evaluation of Phosphorus Recovery as Struvite from Digester Supernatant. Bioresource Technology, 97, 2211-2216.

9. Rahman, M. M., Liu, Y. H., Kwag, J. H., \& Ra, C. S. (2011). Recovery of struvite from animal wastewater and its nutrient leaching loss in soil. Journal of Hazardous Materials, 186(2-3), 2026-2030.

10.Bouropoulos, N. C., \& Koutsoukos, P. G. (2000). Spontaneous precipitation of struvite from aqueous solutions. Journal of Crystal Growth, 213(3), 381-388.

11.Kataki, S., West, H., Clarke, M., \& Baruah, D. C. (2016). Phosphorus recovery as struvite: Recent concerns for use of seed, alternative Mg source, nitrogen conservation and fertilizer potential. Resources, Conservation and Recycling, 107, 142-156.

12. Owen Jr, J., Stoven, H., Kowalski, J., \& Phillips, K. (2009). Assessment of Struvite Containing Controlled Release Fertilizer as a Source of Phosphorus for Containerized Ornamental Crops.

13.Deng, L.-W., Zheng, P., \& Chen, Z.-A. (2006). Anaerobic digestion and post-treatment of swine wastewater using IC-SBR process with bypass of raw wastewater. Process Biochemistry, 41(4), 965-969.

14.Liu, Y., Kumar, S., Kwag, J., Kim, J., Kim, J., \& Ra, C. (2011). Recycle of electrolytically dissolved struvite as an alternative to enhance phosphate and nitrogen recovery from swine wastewater. Journal of Hazardous Materials, 195, 175-181.

15. Shih, Y.-J., Abarca, R. R. M., de Luna, M. D. G., Huang, Y.-H., \& Lu, M.C. (2017). Recovery of phosphorus from synthetic wastewaters by struvite crystallization in a fluidized-bed reactor: Effects of $\mathrm{pH}$, phosphate concentration and coexisting ions. Chemosphere, 173, 466-473. 
16. Battistoni, P., Boccadoro, R., Fatone, F., \& Pavan, P. (2005). Auto-Nucleation and Crystal Growth of Struvite in a Demonstrative Fluidized Bed Reactor (FBR). Environmental Technology, 26(9), 975-982.

17. Ariyanto, E., Niyati, Y., Kharismadewi, D., \& Robiah. (2020). Kinetika Pembentukan Struvite Kristal Menggunakan Zeolit Alam sebagai Adsorben pada Aeration Cone Column Crystallizer. Jurnal Rekayasa Proses, 14(1), 60-73.

18. Anggriawan, R. R., Alvira, F. H., \& Edahwati, L. (2020). Reaction Kinetics of Ammonium Removal from Cow Urine by Struvite Formation Using a Baffle Column Reactor. Chemica : Jurnal Teknik Kimia, 7(2), 99-105.

19.Adiman, T. M. F., Feriyanto, A., . S., \& Edahwati, L. (2020). Mineral Struvite Dari Batuan Dolomit Dengan Reaktor Kolom Sekat. Jurnal Teknik Kimia, 14(2), 85-91.

20.Darmadi. (2014). Pengolahan Limbah Cair Pabrik Pupuk Urea Menggunakan Advanced Oxidation Processes. Jurnal Rekayasa Kimia \& Lingkungan, 10(1), 1-6.

21. Edahwati, L., Sutiyono, Zahra, N., \& Septiani, H. (2020). Magnesium Recovery of Struvite Formation Based on Waste Salts (Bittern) with a Bulkhead Reactor. International Journal of Eco-Innovation in Science and Engineering, 1(01), 1-5.

22. Yetilmezsoy, K., \& Sapci-Zengin, Z. (2009). Recovery of ammonium nitrogen from the effluent of UASB treating poultry manure wastewater by MAP precipitation as a slow release fertilizer. Journal of Hazardous Materials, 166(1), 260-269.

23. Edahwati, L., Sutiyono, S., Suci, P. D. Stefanus, M., Jamari, J., \& Bayuseno, A. P. (2016). Effects of the Optimised $\mathrm{pH}$ and Molar Ratio on Struvite Precipitation in Aqueous System. MATEC Web of Conferences, January.

24. Hamzah, S., Ulum, F., Sutiyono, \& Edahwati, L. (2020). Kinetika Reaksi Pembentukan Pupuk Struvite dari Limbah Cair Tempe Secara Batch. Seminar Nasional Soebardjo Brotohardjono XVI.
25. Fitriana, A. R., \& Warmadewanthi, I. (2016). Penurunan Kadar Amonium dan Fosfat pada Limbah Cair Industri Pupuk. Jurnal Teknik ITS, $5(2)$.

26. Rodrigues, D. M., do Amaral Fragoso, R., Carvalho, A. P., Hein, T., \& de Brito, A. G. (2019). Recovery of phosphates as struvite from urine-diverting toilets: Optimization of $\mathrm{pH}$, Mg:PO4 ratio and contact time to improve precipitation yield and crystal morphology. Water Science and Technology, 80(7), 12761286.

27. Sutiyono, S., Edahwati, L., Perwitasari, D. S., Muryanto, S., Jamari, J., \& Bayuseno, A. P. (2016). Synthesis and characterisation of struvite family crystals by an aqueous precipitation method. MATEC Web of Conferences, 58.

28. Capdevielle, A., Sýkorová, E., Biscans, B., Béline, F., \& Daumer, M.-L. (2013). Optimization of struvite precipitation in synthetic biologically treated swine wastewater--determination of the optimal process parameters. Journal of Hazardous Materials, 244-245, 357-369.

29. Liu, Y., Rahman, M. M., Kwag, J.-H., Kim, J.H., \& Ra, C. (2011). Eco-friendly Production of Maize Using Struvite Recovered from Swine Wastewater as a Sustainable Fertilizer Source. Asian-Australas J Anim Sci, 24(12), 16991705.

30. Iswarani, W. P. dan I. W. (2018). Recovery Fosfat dan Amonium Menggunakan Teknik Presipitasi Struvite. Jurnal Teknik ITS, 7(1), 7-9.

31.Koralewska, J., Piotrowski, K., Wierzbowska, B., \& Matynia, A. (2009). Kinetics of ReactionCrystallization of Struvite in the Continuous Draft Tube Magma Type CrystallizersInfluence of Different Internal Hydrodynamics. Chinese Journal of Chemical Engineering, 17(2), 330-339.

32. Sudarmi. (2013). Pentingnya Unsur Hara Mikro Bagi Pertumbuhan Tanaman. WIDYATAMA, 22(2).

33.P.A.P., W. Y., \& Hendriani, R. (2013). Review Teknik Peningkatan Kelarutan Obat. Farmaka, 14(2), 288-297. 